\title{
Nora's Transcendental Consciousness from Marianne's Sensibility: A Reading of Ibsen's A Doll's House and Austen's Sense and Sensibility
}

Tanzin Sultana ${ }^{1} *$ \& Durdana Nower ${ }^{2}$

${ }^{1}$ Lecturer, Department of English, BGC Trust University Bangladesh, Chandanaish, Chattogram, Bangladesh.

${ }^{2}$ Student, Department of English, BGC Trust University Bangladesh, Chandanaish, Chattogram, Bangladesh.

Corresponding Author: Tanzin Sultana, E-mail: tanzinsultana@bgctub.ac.bd

\author{
ARTICLE INFORMATION \\ Received: August 12, 2020 \\ Accepted: September 15, 2020 \\ Volume: 3 \\ Issue: 9 \\ DOI: $10.32996 /$ ijllt.2020.3.9.21
}

\section{KEYWORDS}

Marianne, Nora, Sensibility, Consciousness, Self-reliance

\section{ABSTRACT}

This paper attempts to bring out the nineteenth century's women's quest for selfrespect and self-actuality in the mirror of Nora's developing consciousness following Marianne's growing sensibility. Jane Austen's Sense and Sensibility, and Henrik Ibsen's A Doll's House are two prominent genres of ninetieth century's English literature where both writers show the contemporary women's soul being entangled to social norms as well as their gradual try to be non-conformist against these norms by their thought and action. In the 19th century, English society creates impediments for unmarried women like Marianne and married women like Nora to think and to talk in their way. It is the patriarchal society where women's social dignity and security depend on their marital status and husbands. Since marriage is their identity, they show their loyalty and sincerity to their husbands or the men they love. In Austen's novel, as an ordinary woman, Marianne takes Willoughby's attention as a scared bonding and challenges the seniors' matured advice. In Ibsen's play, Nora does forgery and secretly takes a loan to save her sick husband's life. She considers it a spouse's duty and believes that her husband will understand her as he cares for her. When the time comes, both Marianne and Nora betray their loyalty from their partners to whom they are not human beings but puppets to be entertained. From this violation of trust, they realize that they need to be considered human beings first before being respected women in a family and society. It is their strength that despite being taken as soulless creatures, they dare to think about own self beyond the society and become self-reliant. Their growing self-reliance makes today's women progressive in creating a space in society and family for themselves as human beings.

\section{Introduction}
"And learns at last that it is self-delighting, Self-appeasing, self-affrighting,
And that its own sweet will is heaven's will,
She can, though every face should scowl And every windy quarter howl
Or every bellows burst, be happy still."

It is Yeats's concern for his daughter (representing every woman) so that she can take possession of intellectuality, independence, and confidence to present her personality. Before him, Ibsen in his A Doll's House and Austen in her Sense and Sensibility also show the same concern for their contemporary women. Through the outspoken characters, Marianne and Nora, both writers celebrate their transcendent dynamism. Transcendentalism is a ninetieth century's movement that forms

K C AL-KINDI CENTER R D FOR RESEARCH AND Your gateway to world-class research
Published by Al-KindiCenter for Research and Development. Copyright (c) the author(s). This is an open access article under CC BY license (https://creativecommons.org/licenses/by/4.0/) 
for men and women equality in thought and action. It is knowledge about oneself, society, or the universe beyond what they see, hear, and feel.

It is "to believe your thought, to believe that what is true for you in your private heart is true for all men - that is genius" (Emerson, 1). Another transcendentalist, Margaret Fuller, also advocates social reformation, especially for women, by enriching self-education, self-creation, self-culture, and single-mindedness. "Fuller, herself a self-actualizing and achieving woman, had the highest faith in the potential of women, and she also had the deepest trust in the likelihood of its realization" (Quawas, 132). Both humanitarians, Emerson and Fuller, hold their pen for a woman to be a human being first in essence and existence. Like a male, they also want a female to lead the way to intellectuality, self-choice, and self-voice rather than surrender to patriarchic society's partial law.

In Sense and Sensibility and A Doll's House, both Marianne and Nora want to create a self-identity through the interpersonal relationship with their loves, Willoughby and Helmer. So, both of them are sincerely faithful to their relationship. "Nora is a self-sacrificial woman who fights to have a practical space for herself in a male-dominated community" (Kurraz, 370). To Nora, marriage is not only social status but such a soul-bonding for which a spouse has to take a risk and compromise for his partner's well-being, respect, and security. When Helmer becomes seriously ill and financially destitute, Nora, as a dutiful wife, stands for her husband and her family as well secretly by breaking social restrictions. She confidentially forges her dying father's signature and takes a loan from Mr. Krogstad, and she knows well that her husband will not allow her to take a loan from an outsider as it is a matter of his social dignity. Because she is sincere about her husband's dignity, she cannot seek help from her father, telling him Helmer's terrible condition. She does not regret her secrete doing as she is loyal to her conscience. She straightly answers Krogstad, "Do you mean to tell me that a daughter has no right to spare her dying father trouble and anxiety? --- that a wife has no right to save her husband's life? I don't know much about law, but I'm sure you'll find, somewhere or another, that is allowed" (Ibsen, 72) But her husband, in his good time, selfishly forgets his love, emotions, and commitments for Nora when by a third force he learns Nora's secrete sacrifice. Instead of appreciating her strong support in his worst time, he blames her and rapes her dignity by questioning her character. This selfish behavior shows Nora the true self of her husband and her place to him and this patriarchal society, and it opens her inner eyes. She understands that before being someone's respected woman, she must be a self-reliant human being. For this, she has to leaves her husband's house to discover herself in solitude.

\section{Social Ideology and Transcendental Power}

Marianne and Nora are the women of that society where women and animals are presented in the same stand. For the women of the ninetieth century, education is too much to get. Though the industrial revolution brings many social changes, there is not much change in the women's fate. They are brought up only to be better house-chores doers and obedient subjects for men who do not like to receive any academic help from the females. Noorbakhsh Hooti brings up, "in the nineteenth century, the most essential duty for a woman is staying at home, raising her children, and serving her husband" (1109). Both married and single women are always at the mercy of their fathers, husbands, or brothers. This society chooses marriage as the only goal for a single woman. Then it makes the woman sacrifice her essence, existence, and identity for the person she marries. Steadily she also obliterates that she has a name, a desire, a dream while being devoted her life to cooking, childbearing, all the maintenance of the family. If she can keep her self- consciousness, and conscience locked, this society is favorable. Otherwise, she has to face the challenges of being non-conformity with society.

Sense and Sensibility is "the story of the impoverished Dashwood sisters, Marianne and Elinor, who tried to find proper husbands to secure their social position"( Hua, 348). Mrs. Dashwood is much tensed for her three daughters' marriage as her dead husband did not keep many fortunes for her daughters. Moreover, her half-son does not bother about his sisters' future, and through his wife; he demands some of the fortunes. Since marriage is to be thought the only way to social security, Mrs. Dashwood does not strictly control the access of admirers like Colonel Brandon, Edward Ferrars, or Willoughby in Elinor and Marianne's life. “Austen's subject is not courtship but marriage ship: marriage is crucial because it is the only accessible form of self-definition for girls in her society. Marriage is one of those subjects that must be read imaginatively from the woman's point of view, which here differs from that of the man" (Hua, 350). That is why young Marianne with her little insight chooses a fictitious man like Willoughby over a decent man like Colonel Brandon. After being enticed from her wrong choice, she becomes more sensible and practical about her life decision.

Such sensible practicality does not make Nora in A Doll's House dead to her husband's worse accusation on her character because "Nora's behavior is controlled by personal subconscious drives and conflicting impulses"(Kurraz, 366). Since society teaches her that marriage is a woman's dignity, Nora determines to fight alone to save that dignity and fails to be acknowledged. Here, Marianne takes the challenges to cope with a man getting married for whom she has no special feeling as she hopes that he may treat her as a human being and respect her feelings and actions. With the same 
transcendental feelings, she challenges to walk out on her eight years of marriage. Here, we cannot demonstrate Marianne as fragile and Nora as egotistic for their final decision because both try to be self-conscious to make their marriage successfully work. We can consider both of them as social reformers of their time, who listen to their soul and watch in the depth of an ocean to give marriage its true definition. Eslamie notes, "the need to understand individuals within their social context" must be based on one's real individuality (97).

\section{Marianne: Passion to Sensibility}

At the beginning of Sense and Sensibility, we find Marianne as idealistic, ecstatic, and romantic. We also find her not matured enough with prudence, intelligence, and resistance. To Austen, "Marianne was sensible and clever, but eager in everything; her sorrows, her joys, could have no moderation. She was generous, amiable, interesting: she was everything but prudent" (10). She judges a man from her romantic ideology, not from logical insight.

If anyone's outlook and approaches match her perfection concept, she blindly gets attached to him. So, despising the social order and her sister's advice, she quickly falls in love with a lascivious young man like Willoughby, who can manage to captivate her heart with his fictitious love and care. "Willoughby was all that her fancy had delineated in that unhappy hour and every brighter period, as capable of attaching her; and his behavior declared his wishes to be in that respect as earnest, as his abilities were strong" (Austen, 43). Even more than a family member, despite knowing a little of Willoughby's intention, she feels him much better trustworthy in sharing love and affection. To her sister, she points out, "I hold myself guilty of greater impropriety in accepting a horse from my brother, than from Willoughby" (Austen, 51).

Marianne knows that Colonel Brandon is deeply in love with her, but she does not allow any humanity in counting that old bachelor's genuine feelings for her. Misunderstanding his pursuits, talents, and genius, she says, "Colonel Brandon is old enough to be my father, and if he were ever animated enough to be in love, must have long outlived every sensation of the kind. When is a man to be safe from such wit, if age and infinity will not protect him?"' (Austen, 34).

Out of the same fascination, she also fails to recognize her sister, Elinor's Edward's choice. She chastises, "Edward is very amiable, and I love him tenderly. But yet something is wanting- his figure is not striking; it has none of the grace which I should expect in the man who could seriously attach my sister" (Austen, 18). She also denounces Edward as spiritless and tame, and a man of no sensible taste as he is not sincerely attached to music. Moreover, she finds no romance in his reading of poetry. When Edward admires Elinor's drawing, Marianne doubts his appreciation to her sister, claiming, "He admires as a lover, not as a connoisseur" (Austen, 18). "According to Marianne, the qualities of the lover and the connoisseur should be united. However, in her criticism of Edward's taste, she seems to prefer connoisseurship, for the connoisseur appreciates art's intrinsic beauty" (Fisher, 216). It is Marianne's immaturity to differentiate between a false admirer and a connoisseur. Like Brandon to Marianne, Edward presents himself to Elinor as he is. To earn Elionor's love and respect, he is sincere and honest in his communication with her and her family because of her sensible approach. If Marianne showed her sensible approach in dealing with men on her highway, she would not have been dashed and deceived by the hypocrite Willoughby. She is beguiled as without proceeding rationally; she readily feels happy and delighted when Willoughby cinematically presents him as a romantic lover, impressively matching his interest with hers and promises to make her his wife in the future. "To Marianne, it had all the distinguishing tenderness which a lover's heart could give" (Austen, 60). So, the ladycharmer, Willoughby, takes the chance of her naïve fascination and plays the game with the little lamb of her mind. When he finds another rich hunting, Miss Sophia Grey, he abandons Marianne ungenerously, keeping her wait in the tide's mid.

Forthwith, Marianne, who always acts and believes with no moderation, cannot take the brutal dump from Willoughby and losses self-control disastrously in front of her family members whose care once she did not care. After a few days, she inclines to be calm, depressed, and isolated from her family and the social attachment for being the sole guide of her judgment. Her generosity is that she wants to give Willoughby a second chance and wait for him as she cannot make her mind accept his fraudulence. She sends him letters after letters expecting his response with love and gets disappointed with the contents of his letters, "Oh, Willoughby, Willoughby, could this be yours! Cruel, cruel- nothing can acquit you.... Willoughby, where was your heart when you wrote those words?"(Austen,149).

She then rationally realizes that she is a woman of extraordinary fate who, at a very budding youth, discovers the distortion of her thoughts and wistfully has to counteract her favorite conducts. After two years of her tragedy, she marries Brandon again with her thought that is now rationally independent. By forgiving Willoughby, she forgives her childish fascination. Her realization that she has no choice but to be self-confident and practical first if she does not want to be psychologically oppressed more and wants to create a personal space in this society. "The soul threatened by the severed relationship must 
feel its future forlorn indeed, stark, bare, desolate" (Aproberts, 352). So, marrying a sensible man like Brandon is a better option to practice self-reliance independently.

\section{Nora's journey to Self-Actualization}

"A Doll's House is a tragedy in which Nora leaves her house by slamming a door to the world of new possibilities. She is going off to know her responsibilities towards herself. This kind of self-realization, which usually leads to a new beginning, is one of Ibsen's main ideologies posed in his play. Nora opens her eyes and observes that her individuality and freedom have been taken in living with Torvald Helmer" (Shah, 346). Nora Helmer is a woman of conscious spirit, seriousness, merriment, aspiration for love, respect, and freedom. She is such a kind-hearted and subtle lady who can easily make a polite attachment with outsiders like Dr. Rank, Krogstad, and her friend, Linda, by receiving and sharing their emotions. If it is about her family and husband's matter, she does not give anyone a chance to interfere as she knows, "there are people one loves, and others one likes to talk to" (Ibsen, 109).

Like a typical housewife, she acts as a submissive and tolerable Helmer bride before the end of the play. She accepts to be his doll in addressing and adoring her as 'featherbrain,' 'songbird,' or 'squirrel' just sustaining a peaceful unity in her house. She is also alert to domestic violence. When Helmer dismisses Nora's recommendation to renew Krogstad's post in the office, she cries out, “Oh, Torvald, call it back again! For my sake, for your own, for the children's sake... You don't know what that letter may bring upon us all" (Ibsen, 97). When Linda wants to know the reason why she does not disclose the truth of taking a loan by a wrong signature, she asserts, "how painful and humiliating it would be for Torvald, with his manly self-respect, to know that he owed anything to me! It would utterly upset the relationship between us; our beautiful, happy home would never again be what it is" (Ibsen, 47). Once again, we see her pragmatic maturity that she hopes to confess the truth to her husband when his passionate love for her will find its platonic ground one fine day. What Nora does is all for her and her family's concern, not what the individuals expect. We also find her self-defense for her husband While Krogstad is demeaning Helmer, "If you talk disrespectfully of my husband, I must request you to leave the house" (Ibsen, 64).

It is Nora's transcendental credence that where is man, there are virtues. She feels that, like her husband, she has the same importance and right in their virtuous bonding. She also believes that what the situation may, like her, Helmer, will also save her dignity. Soon, she realizes that Helmer's soul was never conformist with her soul as she "was astonished to see that and asked to her heart for whom she did all things against society's rules and regulations. For whom Nora took the risk against everything, now ready to handle her with dagger words after receiving the letter from Krogstad (the letter which was inscribed with the truth of Nora's forgery of her father's signature for drawing money from the bank)" (Yeasmin, 336). Instantly, Helmer's indigestible shouting like "During all these eight years-she who was my pride and my joy- a hypocrite, a liar- worse, worse- a criminal "(Ibsen, 154) breaks her heart and trust so harshly that she also feels dejected and betrayed like Marianne in Sense and Sensibility. To Helmer, she is just a passionate object to be pleased and a lifeless doll that dances according to his tune. He levels her with hideous allegations when she tries to actualize her intelligence and virtues in his tough time. Her instant discernment is that in the state of being dependent entirely on someone's intelligence, action, and consent, action-oriented self-actualization is not possible. She always prioritizes her family over herself, which adds no value at the end of her eight years of marriage. "It is easy in the world to live after the world's opinion; it is easy in solitude to live after our own" (Emerson, 5). To be respected as a human being in this society, she has to humanize her doll's image and learn to respect herself first. Again, to live with this self-respect and non-conformity in this multi-opinion world, she has to know herself first in isolation. Remarkably, to guide her morality and prepare herself to be an action-oriented nonconformist of this so-called patriotic social norms, she leaves her ardent family, declaring, "I must stand quite alone if I am ever to know myself and my surroundings, so I cannot stay with you"( Ibsen,166).

She leaves. "Her journey to self-realization happened as a miracle, unexpected, uncertain, but on time. She is the protagonist of this play who lives in decorative surroundings as a doll and finds out that she is nothing but a precious instrument in her husband's hand. This knowledge helps her to strive to find her lost or neglected values in a conventional society" (Yeasmin, 336).

\section{Transcendental Consciousness: A way to Emancipation}

A man finds relief when he can set his heart to his obligations and do his best. For this, we have to accept our highest mind, that is, conscience. Emerson emphasizes, "Trust thyself: every heart vibrates to that iron string. Accept the place the divine providence has found for you, the society of your contemporaries, the connection of events" (2). Before trusting oneself, one has to listen to his highest mind by social detachment because the voice of conscience becomes inaudible and lusterless amid the corrupted society. Indefinitely, to find peace by discovering her true self, desolated and restless Marianne makes herself calm and determined, locking her ears up against social criticism and piety. Like her, Nora also determines to leave 
her social status as Miss Nora Helmer to discover her true self so that she can consciously trust herself by not always relying on anyone for anything major or minor.

Society is here always making conspiracy against the manhood of people, especially that of the women. Patriarchic society creates such a compulsory and partial culture for women to conform to human-made names and norms and be nonconformity with realities and creativities. This much, both Marianne and Nora cannot breathe anymore being too much conformist with this culture because both of them have common desires and demands for freedom, dignity, respect, love, and security, not as feminists but as common human beings. Both of them clearly understand that this masculine society can never value their pure and devoted love for their male partners, where consciously they enumerate them as pleasing objects. Marianne cries, "I felt myself to be solemnly engaged to him as if the strictest legal convent had bound us to each other" (Austen, 148). It is not an engagement of two souls. How can Willoughby break her faith when he has never kept his faith in her love? Marianne accepts it as her imprudence as, like her contemporary women, she never tries to awaken her consciousness and becomes emotionally slaved to deceitful approaches. So, after her disaster with Willoughby, every day, she tries to mend her notion and motion, consciously restore her life and health. She also tries to improve her temper and govern her feelings "checked by religion, by reason, by constant employment" (Austen, 268).

Like Marianne, Nora perceives that her happiness and her pain will never be anyone's object. In her conjugal life, Helmer never takes her any word seriously as to him; she talks like a child. When his child-like wife acts as a mature man, he reacts hideously and calls her a curse for him and his children. Then she also discerns that it is her mistake to love and believe someone much over her-self. Keeping self-reliance in aversion, she will never be treated as a human being until she does non-conformity with this masculine society's false accusation. When she boldly announces to the family to gain more experience about her own identity, he reacts not to allow her to go out, as she is her responsibility. She says that since there is no love and trust in their relationship, he has no authority to stop her.

Moreover, she proclaims that she has some duties towards herself beside her duties towards her husband and children. She asserts, "I am a human being, just as much as you are or at least that I should try to become one" (Ibsen, 167). She knows that this masculine society and human-made religion will show sympathy to Helmer and abhor her as a desperate feminist. Society never expects a woman to behave out of her consciousness and conscience. "Nora carried the slough of a doll in the family initially, but later she stood rigorously not like a doll but as a human being" (Yeasmin, 334).

To Emerson, "Nothing is at last sacred but the integrity of your mind. Absolve you to yourself, and you shall have the suffrage of the world" (4). Therefore, to create their identity as a human being, as the way to emancipation, Marianne starts, and Nora precedes her journey to transcendental consciousness being non-conformist with the social and universal order.

\section{Conclusion}

By birth, every man has the freedom to think and to express. If we wish to live as a human being, we have to work that also concern us, not always concerning other people or society. When we try to be non-conformity with social concerns, society will thrash us with much resentment. Through Marianne and Nora's perilous journey to self-government, Austen and Ibsen's writings show familial and social conflict, gender deconstruction, exploitation, and liberation of consciousness. In early life, both Marianne and Nora are childish, naïve, submissive, and dutiful to their relationships. However, Marianne's choice for attractive and swift spirited men like Willoughby is a fascination; her love for him is genuine and pure as a sacred bonding. Since marriage is a sacred bonding, to save it Nora fights alone secretly in the critical period of her husband's life.

For Willoughby, Marianne does not care any moderation, social concern, and family's warning as she has full trust in her love and in Willoughby, who finally breaks her heart while finding new charm for his pleasure. Nora also keeps her trust in her husband. Therefore, she wants to take time, to tell the truth to him, but her husband's brutal reaction after learning of her secrecy proves that Nora is just a sensuous object. Jackson notes, "Violations of trust can shatter our sense of the world and our place in it. However, to move beyond this subjective sensation and rebuild, we must integrate the experience within the larger context of the world in which we live" (89). Though it takes time for Marianne to realize and move on, Nora directly gets that it is useless to mourn over the lost love and faith that is not meant for her. It is their consciousness that if they do not wish to be the average women like pleasing objects in any kind of society, they have to reform their ideology and restore the power of intelligence first. For this, they have to learn to know themselves and respect themselves behind their social and familial customs. The world will then change its ideology and respect every common woman like Marianne and Nora as a human being. That is the liberation of their soul as nothing is celestial on earth than human nature's straightforwardness to display. Likewise, Emerson says, "Society never advances. It recedes as fast on one side as it gains on the other. It undergoes continual changes; it is barbarous, civilized, Christianized, rich, it is scientific, but this change is not 
amelioration. For everything that is given, something is taken" (19). In this paper, through Marianne and Nora we focus on the $19^{\text {th }}$ century's English women's developing self-consciousness. In the near future, we will focus on the $21^{\text {st }}$ century's women's socio-psychology from different cultures.

\section{References}

[1] Aproberts, R. Sense and Sensibility, or Growing Up Dichotomous. University of California, Riverside. file:///G:/doll's\%20house\%20\&\%20sense-sensiblity/sense\%20and\%20sensibility,\%20dictonomy.pdf

[2] Austen, J. (2017). Sense and Sensibility. Finger Print Classics. New Delhi. Print.

[3] Emerson, R, W. (1841). Self-Reliance. file:///G:/doll's\%20house\%20\&\%20sense-sensiblity/self-\%20reliance\%20text.pdf

[4] Eslamie, R. (2015). An Investigation of Adlerian Psychoanalytic Feminism in 'A Doll's House'. Journal of Scientific Research and Development, 2(1).

[5] Fisher, M. (2010). "Love" and "Connoisseurship" in Jane Austen's SENSE AND SENSIBILITY." The Explicator, 68(4).

[6] Hooti, N. (2011). “Henrik Ibsen's A Doll's House: A Postmodernist Study Theory and Practice in Language Studies" 1(9).

[7] Hua, Ch. (2013). Critical Discourse Analysis of Women's Language at the Lexical Level in Sense and Sensibility. Social Sciences and Humanities, 4(2).

[8] Ibsen, H. (2006). A Doll's House. Friends' Book Corner. Print.

[9] Jackson, R, L. (2000). The Sense and Sensibility of Betrayal: Discovering the Meaning of Treachery through Jane Austen. Humantas, XIII(2).

[10] Kurraz, A, H, Dr. (2015). Harry Sullivan's Theory of Interpersonal Relations in Characterizing Nora's Personality in Henrik Ibsen's A Doll's House. Research Journal of English Language and Literature (RJELAL), 3.

[11] Quawas, R. (2012). Margaret Fuller's Conversations: Speaking as Revision and Feminist Resistance. Studia Anglica Posnaniensia .47(2-3).

[12] Seeber, B, K. (2004). The Hunting Ideal, Animal Rights, and Feminism in Northanger Abbey and Sense and Sensibility. Lumen, 23. https://id.erudit.org/iderudit/1012200ar

[13] Shah, A, R. (2016). The Concept of Feminism in Henrik Ibsen's A Doll's House. International Multidisciplinary Research Journal.

[14] Yeasmin, F. (2018). A Doll's House' is the Backlash of Feminism. International Journal of English Literature and Social Sciences (IJELS), $3(3)$.

[15] Yeats, W.B. (1919). A Prayer for My Daughter. [Online]. Retrieved on August 30, 2020. Available: https://www.poetryfoundation.org/poetrymagazine/poems/14635/a-prayer-for-my-daughter 